\title{
RECENT SOLAR ACTIVITY
}

\author{
By Dr. M. A. ELLISON \\ Royal Observatory, Edinburgh
}

\begin{abstract}
HE present maximum phase of the sunspot cycle is outstanding in many respects. The Zurich relative sunspot numbers (provisional) for the first ten months of 1957 were: $152,117,157$, $175,165,206,194,163,244,263$. These high values for September (244) and October (263) are quite exceptional. If we look back to the beginning of the series in 1749 , the only other monthly means which have exceeded the 200 level were those of May 1778 (239), December 1836 (206), May 1947 (201) and November 1956 (203). We may thus regard the timing of the opening months of the International Geophysical Year as particularly fortunate : to have caught so great a peak of solar activity within its net was a considerable achievement of planning.

The high sunspot numbers of 1957 have been contributed mainly by the occurrence of large numbers of small and medium-sized spot groups. On many days in September and October there have been upwards of twenty such groups present on the disk at one time. On the other hand, the giant $F$-type sunspots which were such a characteristic feature of the last cycle, in the years 1946-51, have been noticeably few. It is spots of this type, possessing complex magnetic fields ( $\beta \gamma$ and $\gamma$ ), which give rise to the most intense $(3+)$ solar flares, and these have likewise been less frequent than the high sunspot numbers would lead one to expect.

Another unusual feature has been the continued appearances of occasional spots in high latitudes, such as are characteristic of the early years of the cycle. One of these groups, in latitude $46^{\circ} \mathrm{S}$., crossed the central meridian on September 15 and lasted for at least seven days.

September also provided something like a record in magnetic activity: there were, in all, six great storms with sudden commencements, beginning on September 2, 4, 13, 21, 22 and 29. Two regions showing high flare activity (one in $20^{\circ} \mathrm{N}$. and the other in
\end{abstract}

\section{ECOLOGY OF GRASSLANDS}

$\mathrm{O}^{\mathrm{s}}$ September 11 in Dublin, Section K (Botany) and Section $M$ (Agriculture) of the British Association held a joint session under the chairmanship of Prof. J. Doyle on "The Ecology of Grasslands". Mr. C. E. Hubbard opened with a paper on "Genetical and Ecological Variation of the Components of Grasslands in the British Isles". Speaking as a taxonomist, Mr. Hubbard pointed out that while the botanist was primarily interested in characters distinguishing taxa and especially those indicative of relationship, the agriculturist was essentially concerned with characteristics likely to be of value for grassland improvement and only those varieties likely to be of economic importance were of prime interest to him. Variability in grass populations had long been recognized. A. F. Gray in 1821 recorded seventy-five varietios of wild British grasses, while nowadays the number of intraspecific variants recorded exceeded four hundred. Mr. Hubbard then presented a classification of grass variants and distinguished between those of some taxonomic sig- $30^{\circ} \mathrm{S}$. latitude) crossed the Sun's central meridian on August 31, and to these must be attributed the great geomagnetic disturbances during September 2-5. One of the few $F$-type sunspots developed rapidly from September 14 onwards, crossing the central meridian on September 19. This region generated a high level of activity-at least a dozen flares were observed here in the class 2 and 3 categories - and was undoubtedly responsible for the magnetic storms on September 21 and 22. Another active group, with central meridian passage on September 27, was the probable cause of the storm on September 29.

Prof. J. Bartels reports that, for September, the monthly average of the daily planetary magnetic amplitudes, $A p$, in the usual unit of 2 gamma, was 49. The next highest monthly averages in the available series (1932-33, and 1937 to date) were 40 (September 1951) and 37 (March 1940). September had three days with $C p=2.0$ and five days with $C p=1 \cdot 9$.

Some thirty-six sudden ionospheric disturbances (cases of $D$-layer absorption due to solar flares) were recorded in Britain during daylight hours in September. Many of these produced severe fade-outs on $18 \mathrm{Mc} / \mathrm{s}$. and lower frequencies, such as are usually associated with flares of classes 2 and $3 . \quad F$-layer radio reception with North America was particularly disturbed, especially at the times of the large magnetic storms referred to above.

Although the sunspot number for October exceeded the high value in September, active solar regions were loss pronounced and their terrestrial effects were on a considerably smaller scale. A 3 + flare, observed at the McMath-Hulbert Observatory, reached its peak intensity at about $17 \mathrm{~h} .00 \mathrm{~m}$. on October 20. This outburst would appear, on a provisional view, to have been the most likely souree of the magnetic storm particles which began to affect the ionosphere on the afternoon of October 21.

nificance and others of a more trivial nature. Diseased or abnormal states were seldom of any ecological or genetical significance. Colour variants, however, might be due to ecological or genetical factors: the colour-spikeleted forms of Deschampsia caespitosa, for example, were definitely genetical in character. Albinism, on the other hand, when almost complete, usually led to early death. Partial albinism producing variation, however, was often an unstable condition, and reversion was not unusual. Anatomical variation included the pruinose and glaucous condition due to a waxy surface layer or a thick cuticle, and the rigidity or otherwise of a grass depending on the amount and arrangement of sclerenchymatous tissue. This last condition was probably of ecological significance only. The degree of hairiness of a grass was a very variable factor. Some genetically fixed hairy variants existed, but the range of hairiness of the spikelets found, for example, in a population of the microspecies of the Bromus mollis complex was doubtless due to hybridization. A number of trivial 
modifications in the spikelets, such as extra florets or the presence or absence of awns, appeared in some instances to be due to edaphic factors.

There were many variants distinguished by differences in vigour and size which occurred in a number of polyploid complexes. The collective speciesAgrostis stolonifera, Phleum nodosum and Dactylis glomerata-provided examples of paired genetical variants with distinct ecological requirements and size differences. Differences in spikelet size might be due either to genetical or ecological factors.

In a closely grazed grassland the constituent grasses under cultivation as spaced plants showed obvious distinctions in growth form. These had arisen as a result of different forms of managements and maintained their special characteristics under cultivation. Differences in growth-rate and flowering time of geographical races of herbage plants provided grazing over a longer period than single strains when sown together.

The question of self- and cross-fertility was then considered by Mr. Hubbard. It had been noted that most annuals were self-fertile, whereas many perennials were cross-pollinated and often self-sterile. Annuals, as might be expected, tended to have fewer outstanding variants. The polymorphism seen in perennials might arise from intraspecific crosspollination, interspecific hybridization and some intergeneric crossing. Of interspecific hybrids, thirtyone were known in the British flora, occurring in fourteen genera, six of them annuals and twenty-five perennials. The outstanding polymorphism of Molinia coerulea was probably due to ancient hybridization. Cytological investigation here was highly desirable. In the British Isles nine intergeneric hybrids were known involving five or six pairs of genera. Most of them were rare, but one of them, Festulolium loliaceum, was widely distributed.

The cause of some outstanding examples of variability might be due to the presence of two or more members of a polyploid series in a taxon. For example, Holcus mollis included strains with twentyeight, thirty-five and forty-two chromosomes; and it was possible that polyploidy might account for other species exhibiting well-marked morphological differences associated with special habit preferences.

The phenomenon of apomixis demonstrated in Scandinavia for Poa pratensis did not appear to have been proved experimentally in Britain, but it was probable that the position was similar. It appeared feasible that variation in species of Calamagrostis, Deschampsia, Sieglingia and Puccinellia might also be due to apomixis.

Finally, Mr. Hubbard outlined the possible development of natural grassland in the British Isles. Grasses from south and east following retreating ice-sheets of the last Ice Age produced a genetically mixed basic stock which became augmented by accidental introductions and later by intentional additions by man. Plant-breeding stations continued to distribute improved strains which were gradually replacing the indigenous strains in ancient pastures and meadows. Whother it was desirable to replace such strains, selected naturally through a long period of time, by a few selected strains was a debatable point. Mr. Hubbard contended that native strains in Britain should be preserved in as many regions as possible as a reserve from which to make selections for the grasslands of the future.
Prof. M. J. Gorman then followed with his paper on "The Influences of Biotic Factors on Natural and Semi-natural Grassland". He dealt specifically with the permanent grasslands of Ireland and opened by reforring to the extent of pasture, old meadows and rough grazings which had remained undisturbed for long periods. The character of herbage was primarily dependent on the nature of the soils, but was ultimately determined by management. What the ecologist called the biotic factor was in a general way what a farmer described as management. Tho grazing animal, mowing, harrowing and all differential treatments were contributing factors. The intensity of grazing in the Curragh, for example, kept the heather under control and it was seen only at the margins. In Ireland, grass grew readily in response to a sufficiency of rain uniformly distributed. The soil varied and with it the primary vegetation. On poor soils the plants were of poor stature and adapted to poverty conditions. On the richer soils the plants were of good stature, such as perennial rye grass, meadow fescue, tall fescue and tall oat grass.

However, it was the management, or the biotic factors, that ultimately determined the botanical composition of the sward. The actual quantity of fodder produced was dependent on the soil and rain, but the botanical composition of the sward depended ultimately on the grazing animal. The animal operated in response to the relative palatability of the species present, and this was the more important factor in determining the balance of plants in the community. Linnæus's experiments, more than two hundred years ago, on palatability were unfortunately conducted on plucked plants which were then offered to the animals. It was known that animals would eat almost any plant that was offered to them, even poisonous species. They would devour ragwort in hay, yew clippings, and poisonous roots thrown up by drainage oporations. In the growing condition such plants rarely caused casualties. The most palatable of grasses appeared to be timothy grass and red fescue, whereas the bents seemed to be less appetizing and for that reason tended to dominate very old pastures. The grazing animal, in fact, had left its mprint on the entire countryside. In recent years the doarth of rabbits had meant the disappearance of ragwort in certain areas, since grasses such as red fescue had been able to develop and crowd it out.

Prof. Gorman then showed colour slides of what he described as typical grasslands and some showing biotic factors at work. Many in the audience were horrified at the various shots of herbage which appeared to be dominated by such weedy species as the bulbous buttereup, ragwort, Centaurea scabiosa, Leontodon, thistles, Ulex gallii and others. Prof. Gorman conceded, however, that grasslands of high quality existed in various parts of Ireland, but at the same time gave the impression that such weedinfested areas were not uncommon. The unsatisfactory state of such grasslands had apparently boen due to overgrazing by different animals at different times, with the consequent domination of ungrazable and unpalatable species. Although much could be done by liming and the use of fertilizers, only improved management and effective weed control could successfully deal with the problem, though long years of neglect had added to the difficulty. Much expense and labour would be necessary to carry out what must inevitably prove to be a long-term project. 
The Weeds and Seeds (Ireland) Act passed by Parliament in 1908 endeavoured to cope with the problem, but in spite of heroic efforts the success of the Act as a 'biotic factor' had been strikingly unspectacular.

Dr. R. F. Hunter, of the Hill Farming Association, was unable to deliver in person his paper on "The Pasture-Animal Relationship on Hill Grazings", and Mr. A. R. Wannop, director of the Association, read it for him. The paper dealt with hill sheep farming, and in particular the management system known as the bordor hefting system. This prevailed wherever the stocking intensity lay between one and a little less than two and a half acres per sheөp. The flocks were maintained throughout the year on the hill ground, with perhaps a little hay in severe weathor. A representative heft included about 150 owes, and on the particular heft selected for study there were about 130 ewes plus hoggets on an area of about 250 acres. The plant communities included Nardus, Calluna, Molinia and Agrostis-Festuca combined with bracken. Experiments were carried out to determine the relative grazing values of these communities. The attention given by the sheep to a particular community was assumed to be a measure of its value. The work was carried out at Sourhope in the Cheviot Hills on a heft sloping up from $900 \mathrm{ft}$. altitude to approximately $1,750 \mathrm{ft}$. The sheep were observed from a hut in which was arranged a piece of apparatus designed by Dr. Hunter and christened a 'sheeposcope'. 'This consisted of a powerful telescope, covering most of the heft, with which was coupled a mechanism capable of plotting the exact position of any animal on a map of the area. It was possible to plot with great accuracy the exact position of all the 150 or so sheep in 10-15 min. Observations, started in September 1956, were made once every hour from dawn until dusk at approximately woekly intervals. Meteorological data were also assembled to determine whether or not sheep behaviour had any connexion with meteorological events.

A number of graphs illustrating the results of the observations on particular plant associations were then shown. It was seen that on the Nardus areas, 5 per cent of the total heft, 16 per cont of the sheep were observed. As an index of grazing intensity, the figure of 100 was allotted to a community which was neither favoured nor disfavoured. A figure less than this indicated an avoidance; one greater showed a preforence. The grazing of grass below bracken was generally high, since bracken was only about $2 \mathrm{ft}$. tall and not particularly dense. Variation in grazing intensity was seasonal, being high during September-October and again during March-April. The graph for Molinetum showed a low grazing intensity with some degree of seasonal variation and was definitely not favoured by sheep. Another community consisting of a mixture of Molinia, Juncus squarrosus and heather, the latter being dominant, also showed a low grazing intensity. The Nardetum curvo demonstrated a consistently low grazing intensity, being favoured by the sheep only in the winter. On the other hand, the Agrostis-Festuca community had a high intensity throughout the year.

Dr. Hunter had compared his results with similar observations carried out during 1950-52 in the Lammermuir Hills, and, in general, results showed $a_{4}$ fair correspondence. Such discrepancies as occurred wore explained by the differences in percentage composition of the communities of the corresponding hefts. It was concluded that variation in grazing intensity was modified according to the types of communities and the varying proportions they bore to the heft as a whole. Two broad generalizations arose from the results. First, wide differences existed between the grazing intensities of different communities. Secondly, the seasonal variation in intensity appeared to be a characteristic of the community whenever it occurred in association with others.

Dr. Hunter's paper then discussed the connexion between these conclusions and the work of the ecologist and those concerned with the improvement of hill pasture. 'The botanical composition of the pastures would obviously be affected by wide differences in grazing intensities. The improvement of these hill pistures, however, presented a number of probloms. Should one tackle the heavily grazed communities or those which under froe grazing conditions are little utilized ? It was Dr. Hunter's opinion that an improvement of the Molinia and Nardus areas would be advantageous. Nevertheless, in improving pastures there would be difficultios in fencing off improved aroas to control the grazing. Many questions remained unanswered. It was concluded, however, that an understanding of the grazing preferences of sheep under free-ranging conditions might help to predict whethor the improvement brought about would be utilized in such a way as to lead to an improvement of overall utilization of the pasture as a whole.

The session ended with a long and spirited discussion on many of tho points raised by the speakers.

\section{F. BALLARD}

\section{FUNDAMENTAL RESEARCH ON PAPER-MAKING FIBRES}

$T$ $\mathrm{HE}$ activities of the Technical Section of the British Paper and Board Makers' Association are usually deliberately organized so as to appeal to all classes of members. The symposium entitled. "Fundamental Aspects of Fibres and their Treatment for Papermaking", held at Cambridge during September 23-27, was therefore a unique departure from custom. Its object was to assemble together prominent workers in this field from all parts of the world, for the purpose of prosenting papers for discussion at the highest possible academic level.

The success of the experiment may be judged from the fact that of some two hundred persons attending, about one half were from overseas, and these included many well known for their work in specialized fields of fibre research. Soventeen overseas nations were represented.

Social features were provided in the form of evening conversaziones, a theatre visit, and an excursion to Ely and Norwich. These, however, appoared to supplement opportunities for discussion on the more serious business of the symposium rather than to provide a relaxation, and this despite the full official programme. To many of the overseas visitors the atmosphere of Cambridge, despite the bad weather, was an attraction in itself; and the lecture hall and residential facilities made available by the University authorities were greatly appreciated.

After Sir Geoffrey Taylor had welcomed the participants, Session 1, dealing with the morphology of pulp fibros, was opened under the chairmanship of Dr. W. Holzer. Prof. A. Frey-Wyssling (Switzerlinnd), 